\title{
The role of psychological contract on employee commitment and organisational citizenship behaviour: A study of Indonesian young entrepreneurs in management action
}

\begin{tabular}{|c|c|}
\hline \multicolumn{2}{|c|}{$\begin{array}{l}\text { Authors: } \\
\text { Ade I. Anggraeni } i^{1,2} \text { ( } \\
\text { Christantius Dwiatmadja }{ }^{3} \\
\text { Ahyar Yuniawan }{ }^{1}\end{array}$} \\
\hline \multicolumn{2}{|c|}{ 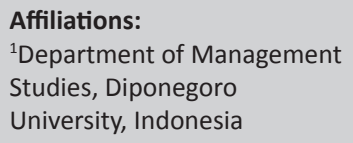 } \\
\hline \multicolumn{2}{|c|}{$\begin{array}{l}{ }^{2} \text { Department of } \\
\text { Management, Jenderal } \\
\text { Soedirman University, } \\
\text { Indonesia }\end{array}$} \\
\hline \multicolumn{2}{|c|}{$\begin{array}{l}{ }^{3} \text { Department of } \\
\text { Management, Satya V } \\
\text { Christian University, } \\
\text { Indonesia }\end{array}$} \\
\hline \multicolumn{2}{|c|}{$\begin{array}{l}\text { Corresponding author: } \\
\text { Ade Anggraeni, } \\
\text { aianggraeni.psdie.undip@ } \\
\text { gmail.com }\end{array}$} \\
\hline \multicolumn{2}{|c|}{$\begin{array}{l}\text { Dates: } \\
\text { Received: } 10 \text { Sept. } 2016 \\
\text { Accepted: } 05 \text { Apr. } 2017 \\
\text { Published: } 30 \text { May } 2017\end{array}$} \\
\hline \multicolumn{2}{|c|}{$\begin{array}{l}\text { How to cite this article: } \\
\text { Anggraeni, A.I., Dwiatmadja, } \\
\text { C., \& Yuniawan, A. (2017). } \\
\text { The role of psychological } \\
\text { contract on employee } \\
\text { commitment and } \\
\text { organisational citizenship } \\
\text { behaviour: A study of } \\
\text { Indonesian young } \\
\text { entrepreneurs in } \\
\text { management action. SA } \\
\text { Journal of Industrial } \\
\text { Psychology/SA Tydskrif vir } \\
\text { Bedryfsielkunde, 43(0), } \\
\text { a1409. https://doi.org/ } \\
\text { 10.4102/sajip.v43.0.1409 }\end{array}$} \\
\hline \multicolumn{2}{|l|}{ Read online: } \\
\hline 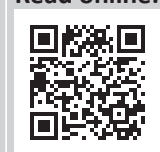 & $\begin{array}{l}\text { Scan this QR } \\
\text { code with your } \\
\text { smart phone or } \\
\text { mobile device } \\
\text { to read online. }\end{array}$ \\
\hline
\end{tabular}

Authors:

Ahyar Yuniawan

Affiliations:

Studies, Diponegoro

${ }^{2}$ Department of

Management, Jenderal

Soedirman University

${ }^{3}$ Department of

Christian University,

Ade Anggraeni,

aianggraeni.psdie.undip@

Accepted: 05 Apr. 2017

How to cite this article:

Anggraeni, A.I., Dwiatmadja,

\& Yuniawan, A. (2017)

contract on employee

commitment and

Indonesian young

entrepreneurs in

Journal of Industrial

Psychology/SA Tydskrif vir

dryfsielkunde, 43(0)

a1409. https://doi.org/

to read online.
Orientation: This study aims to analyse the entrepreneurship-driven reasons and characteristics of employee management of the young generation, by analysing the role of psychological contract on employee commitment and organisational citizenship behaviour in the light of the characteristics of the millennial generation as the owners of small and medium-sized enterprises.

Research purpose: The main objective of this study was to empirically analyse the effect of the psychological contract and organisational support on the organisational commitment and organisational citizenship behaviour of the employees of small-scale enterprises run by young entrepreneurs, especially in the cohort generation.

Motivation for the study: This study attempts to analyse the characteristics of the millennial generation as the owners of small and medium-sized enterprises (SMEs) in running the business by examining their managerial characteristics in managing workplace relationship that aims to achieve the stakeholder expectations and improve both commitment and organisational citizenship behaviour of employees.

Research design, approach and method: Data were collected in the SMEs owned by young entrepreneurs in a city in Indonesia involving 150 respondents. The research model was tested using Structural Equation Modelling with analysis of moment structure (AMOS).

Main findings: The results showed that the employee citizenship behaviour is influenced by the organisational commitment. The commitment of employees was formed by the ability of business owners to understand the needs and expectations of employees regarding opportunities of selfdevelopment, pleasant working environment, the benefit as the workload and the work challenge.

Practical and managerial implications: This study implies the need for academic institutions and policy makers to get involved in addressing the rising phenomenon of entrepreneurship among the young generation.

Contribution and added-value: This study mainly considered the characteristics of young entrepreneurs as the main factor in explaining the success of employee management relationship of SMEs.

\section{Introduction}

Entrepreneurship has been a massive movement nowadays affecting the economic level and social conditions of a country (Choi \& Majumdar, 2014; Ridley-Duff \& Bull, 2015). Job creation, innovative products and the pursuit of productivity are the main business activities mainly attributed to entrepreneurship (Koe, Sa'ari, Majid \& Ismail, 2012). Therefore, every country is arguably willing to do everything possible to encourage the supportive business environment capable of inspiring the emergence of entrepreneurs.

Moreover, entrepreneurial orientation is closely linked with self-initiative and self-employed being generally associated with young people (Burstein, 2013; Ferri-Reed, 2015; Koe et al., 2012). Hence, creating young entrepreneurs and improving their participation will be an effective strategy to promote the level of entrepreneurship (Rahman et al., 2016; Van Praag, 2003). However, although entrepreneurial programs have been largely examined by scholars and executed by

Copyright: @ 2017. The Authors. Licensee: AOSIS. This work is licensed under the Creative Commons Attribution License. 
government, the applicability in the youth has attracted limited attention. To date, examination of young entrepreneur characteristics, partially the millennial generation on entrepreneurship, remains unclear.

Millennial generations are frequently referred to as capitalists who are highly committed to performing business by any means to serve the interests of stakeholders of suppliers, employees and customers. As the first generation living totally immersed in digital technology (Kilian, Hennigs \& Langner, 2012; Kraft \& Wang, 2010; Sago, 2010 Taylor, 2012), providing the identities of cultural and social attitudes, millennial generations are also highly sensitive to community development of both local and global sphere (Nelson, 2015; Yadin, 2012), which in turn have more focus on communality than individuality (Pendergast, 2010). The millennial generation is characterised as informative and expressive in creative ideas and personal values to align the expectations between the owners and employees. Flexibility and responsiveness to the employees are other unique characters of the generation (Moscardo \& Benckendorff, 2010; Pendergast, 2010). The millennial generation also seek to motivate their employees to become more involved and contributing in the formulation of strategy and business decision making (Richardson, 2010). This generation is more positive and optimistic in looking at the aspects of the recruitment and development of employees as one of the main components of business planning.

Flexible social relationships become the central feature in the business management of the millennial generation. Nevertheless, this millennial is very demanding for the professional capabilities of employees. Hence, the relationship between employees and business owners is characterised as flexible but productive. In the context of organisation size, this character is relevant to the study of Harney and Dundon (2006) divulging that the characteristics of human resource management in small and medium-sized enterprises (SMEs) culture are mainly characterised by informality and non-bureaucratic. The employment relationship in this context can be built through the concept of relational aspects of the psychological contract that specifically focuses on the efforts to fulfil the needs of employees. The fulfilment of these needs is more likely potential to increase the employees' attachment to their company through the internalisation of the norms and company values. Therefore, the improvement of commitment to the company makes them willing to be more concerned to achieve the company's goals (Rhoades, Eisenberger \& Armeli, 2001).

Hence, this study attempts to analyse the characteristics of the millennial generation as the owners of SMEs in running the business by examining their managerial characteristics in managing workplace relationship that aims to achieve the stakeholder expectations and improve both commitment and organisational citizenship behaviour (OCB) of employees. This article proposes the antecedents of organisational support and the role of psychological contract that affects employee commitment and OCB.

\section{Theoretical review and hypotheses Organisational citizenship behaviour}

The concept of OCB was first introduced empirically by Smith, Organ and Near (1983) which refers to the thoughts of Chester Barnard in 1983 regarding the individual's desire to work in an organisation. This concept was juxtaposed with the Katz's (1964) concept of specific employee performance, namely, spontaneous and innovative behaviour. OCB is described as the employees' behaviour and the employees' personal choice to work beyond the expectations of the organisation that are required explicitly in the formal job description (Organ, 1997; Shahin, Shabani Naftchali \& Khazaei Pool, 2014; Williams \& Anderson, 1991).

The OCB refers to one of the employee behaviours, that is, the personal choice of the employees to work and behave out of the job description given to effectively achieve the organisational goals (Organ, 1997). This concept is often referred as the extra-role behaviour (Van Dyne, Graham \& Dienesch, 1994), pro-social behaviour (O'Reilly \& Chatman, 1986), spontaneity (George \& Jones, 1997) and contextual employee performance (Borman \& Motowidlo, 1997). Based on the literature review on the concept of extra-role behaviour, Podsakoff, MacKenzie, Paine and Bachrach (2000) concluded that there are nine dimensions forming this concept: cooperative attitude, tolerance towards an appropriate condition of working, good self-enhancement of a positive deed, loyalty to the organisation, internalisation of the organisation aspects, the behaviour of helping at work, tolerance towards the uncomfortable work place, the effort to developing positive organisational, responsibility and constructive organisational.

\section{The influence of the psychological contract to the organisational commitment and organisational citizenship behaviour}

In the human resources management literatures, the concept of the psychological contract refers to Argyris' (1960) study. Rousseau (1989), Guest (2016), Van den Heuvel, Schalk and Van Assen (2015), Panaccio Henderson, Liden, Wayne and Cao (2015), Low, Bordia and Bordia (2016), Karagonlar, Eisenberger and Aselage (2016) further described the psychological contract as the trust of both parties on the reciprocal agreement in which some contracts must be accomplished, some contributions are needed, and some liability must be attained. Even though this concept further facilitates the intangible aspects, which were first applied in the form of formal relationship between the organisation and employees, it merely related to intangible aspects such as salaries (Kiazad, Seibert \& Kraimer, 2014a; Lee \& Lin, 2014). Psychological contract is often defined as the employees' perception of the implicit agreement between themselves and the organisation that contains a shared responsibility between the two parties (Festing \& Schäfer, 2014; Ng, Feldman \& Butts, 2014).

The difference between the psychological and formal contract is that the psychological contract tends to be implicit (Guest, 2016; Karagonlar et al., 2016; McInnis, Meyer \& Feldman, 
2009). Flood, Turner, Ramamoorthy and Pearson (2001), Coyle-Shapiro and Kessler (2000), Sturges, Conway, Guest and Liefooghe (2005), Low et al. (2016) revealed that the psychological contract focusing on employee career development influences the effective commitment of employees. The fulfilment of the aspects contained in the job contract is more likely to give the employees a sense of emotional attachment to the organisation (Kiazad, Kraimer \& Seibert, 2014b; Meyer \& Allen, 1997; Rayton \& Yalabik, 2014). Thus, the hypothesis can be formulated as follows:

H1: The psychological contract significantly influences the organisational commitment

Thomas, Ravlin, Liao, Morrell and Au (2016), Morrison and Robinson (1997) suggested that the psychological contract consisted of the transactional and relational contracts. The transactional contract is associated with the short-term oriented financial liabilities and does not require a deep involvement in the relationship between the employee and the organisation (Guchait, Cho \& Meurs, 2015; Thomas et al., 2016). For example, an organisation pays the employee's salary limited to the contributions of employees according to job description. In contrast, relational components are broader, long-term oriented liabilities and based on broader elements such as socioemotional commitment and trust of the employees.

The psychological contract is basically built to create stability in the working environment and improve the relationship between the organisation and the employee (Beardwell, Holden \& Claydon, 2004; Karagonlar et al., 2016; Low et al., 2016; Sparrow and Cooper, 1998). Hui, Lee and Rousseau (2004) stated that the relational contract highly relates to the citizenship behaviours and the transactional contracts affects the OCB only if mediated by instrumental beliefs. When employees consider that the organisation is able to facilitate their expectations and focuses on a long-term oriented relationship, they will show extra-role behaviour (Kiazad et al., 2014b; Panaccio et al. 2015). Chen and Kao (2012), Priesemuth and Taylor (2016) found that the psychological contract influences an OCB. Furthermore, Coyle-Shapiro and Kessler (2000) explained that relational contracts positively influence the citizenship behaviour of employees:

H2: The psychological contract significantly influences the organisational citizenship behaviour.

\section{The effect of the organisational support to the organisational commitment and organisational citizenship behaviour}

Organisational support is defined as employees' perception on the working environment and conditions established by the organisation as a form of organisation's awareness, appreciation and efforts to facilitate employee contributions (Eisenberger, Huntington, Hutchison \& Sowa, 1986; Eisenberger, Malone \& Presson, 2016; Kim, Eisenberger \& Baik, 2016; Shen et al., 2014). Organisational support strengthens the positive assessment of employees both cognitively and emotionally to the organisation (Byrne \& Hochwarter, 2008; Ristig, 2009). The support is not only limited to the form of salary increasing and financial rewards, but also largely provides an opportunity for employees to optimise their ability to complete the jobs (Bentley et al., 2016). When organisational support is assumed as an important element in fulfilling the socio-emotional needs of employees, the organisation is considered to be well-prepared and able to appreciate the employees in financial honours (Rhoades et al., 2001) and emotional support to the employee performs the job effectively (Eisenberger et al., 1986). This support can be implemented in fair treatment in the implementation of policies and procedures of organisational resource allocation as well as specific organisational decisions such as promotions.

Aubé, Rousseau and Morin' (2007) study conducted on 249 employees in Canada by using cross-sectional research design revealed that the organisational support significantly effects on organisational commitment of employees. Furthermore, Kim et al. (2016), Panaccio and Vandenberghe (2009), Rhoades et al. (2001) showed the positive effect of the organisational support towards affective commitment of employees. Mowday, Porter and Steers (1982) explained that the job features and work experience affect the emotional aspects of the employees. When employees perceive that the company takes care and rewards their contributions, the employees will feel emotionally attached to the company (Allen \& Shanock, 2013). Therefore, we formulated the following hypothesis:

H3: The organisational support significantly influences the organisational commitment

Organisational support improves a good impression in the minds of employees and then, encourages employees to accept the organisation goals and values, and effectively improves their attitude and behaviour (Jain, Giga \& Cooper, 2013; Kim et al., 2016; Moorman, 1991). Organisational support encourages positive attitudes of employees and comfortable condition of working (Saks, 2006). Hu, Wang, Yang and $\mathrm{Wu}$ (2014), Miao (2011) revealed the positive influence of organisational support on the OCB that is reflected by helping their partners or co-workers at work office in completing the task and giving innovative suggestions for the operational activities of the organisation:

H4: The organisational support significantly influences organisational citizenship behaviour

\section{The influence of the organisational commitment to the organisational citizenship behaviour}

Organisational commitment is referred to the employees' statement to internalise and engage in achieving the goals of the organisation (Steers, 1977; Xerri \& Brunetto, 2013). The commitment needs the identification and involvement of employees to the organisation (Steers, 1977). Furthermore, Allen and Meyer (1990) proposed three components of commitment, namely, affective, continuant and normative commitment. Affective commitment focuses on the emotional closeness of employees to the company. Continuant 
commitment is translated as the consideration of benefit of the employees so that they make a decision to join the company, while normative commitment refers to the employee's feelings to fulfil their responsibility or obligation in an organisation.

Davoudi (2012), Gautam, Van Dick, Wagner, Upadhyay and Davis (2005) revealed that the three types of normative and affective commitment significantly affect the OCB of employees. Similarly, Chun, Shin, Choi and Kim (2013), Meyer and Herscovitch (2001) found that the organisational commitment affects the extra-role behaviour. Thus, the hypothesis can be formulated as follows:

H5: The organisational commitment significantly influences organisational citizenship behaviour.

\section{Research design Research approach}

Quantitative approach was used in this study. This approach aims to construct and develop mathematical model of data analysis to prove the hypotheses (Given, 2008).

\section{Research method}

\section{Research participants and procedure}

This research was conducted on the SMEs owned by young entrepreneurs that characterised as the millennial generation in the city of Purwokerto, Central Java. The study used purposive sampling technique, with the number of respondents being 150 . Hair, Anderson, Tatham and Black (1992) suggested that the minimum sample size in a research by using structural equation modelling (SEM) was 100 respondents.

A total of 17 small-scale enterprises run by young entrepreneurs were involved in this study, consisting of education business ( 2 enterprises), automotive (2), cellular phone distributors (2), beauty shop (9), trading (1) and printing business (1). Of all, 13 of which had run more than 5 years. Moreover, overall entrepreneurs run the business after they had graduated from college.

A total of 57 respondents were male, compared to the 67 female respondents. Most of them were 20-30 years old (89 respondents). Majority of respondents (56 respondents) have been working for about 2 years.

Data were collected by using a questionnaire, with the Likert scale of 1 (strongly agree) to 10 (strongly agree). The questionnaires were given to employees of small-scale businesses owned by the millennial entrepreneurs. Response rate of respondents was $95.3 \%$ or 143 that were returned. Nine questionnaires were incomplete and 10 were invalid, thus they could not be analysed in the next step. Finally, 124 questionnaires were further processed.

\section{Measuring instrument}

The questionnaire consists of two main parts. The first part contains the identity and social demographics profile of the respondents, such as age, sex, level of education and the duration of working. In addition, the study also used interviewing techniques with business owners about the reasons to run business, the duration of the business that has been running and the considerations in hiring the employees. While the second part concerned about the questions related to psychological contract, organisational support, organisational commitment and OCB.

Psychological contract: This variable is adopted from items developed by Herriot and Pemberton (1997), Rousseau (1995), namely, the opportunities for self-development, a pleasant working environment, challenging work and the remuneration according to workload.

Organisational support: The variable is adopted from organisational support concept proposed by Eisenberger et al. (1986), consisting of by four items, namely, the encouragement to take the initiative, the freedom to take decisions, the opinions of the employees and the appreciation of the work.

Organisational commitment: The variable is adopted from items developed by Steers (1977), including the employees' emotional bond to the organisation, pride of being part of the organisation, the inspiration to the achievement and great respect for organisational values.

Organisational citizenship behaviour: This variable is measured by four items adopted from Organ (1997), Williams and Anderson (1991), including giving innovative suggestions, helping partners, keeping the organisational image and working outside working hours.

\section{Statistical analysis}

The data were analysed using SEM. SEM is a mathematical model combining algorithms and statistics to find relationships among the variables. This model includes factor analysis, path analysis and regression. This analysis has an advantage regarding the characteristic of SEM focusing more on latent constructs in the form of abstract psychological variables. In this study, the variables were divided into two categories, exogenous and endogenous. Exogenous variables were psychological contract and organisational support, while endogenous variables were organisational commitment and organisational citizenship behaviour.

To test the instrument validity, this study used the comparison between the value of corrected item-total correlation and the value of $r$ table in which the accepted significance level was 0.05 or $r$ table 0.176 . The reliability testing used Cronbach Alpha value limit of 0.6. For determining the model fit, this study used the comparison between the testing value and the cut-off value of indicators including goodness of fit index (GFI), Tucker-Lewis index (TLI), CMIN/DF (comparative fit index) and RMSEA (root mean square error of approximation) (Hu \& Bentler, 1999). Finally, to test the hypotheses, this study used critical value (CR) value and significance level less than 0.05 at $95 \%$ confidence level. 


\section{Results}

\section{Validity and reliability}

Validity test is applied to determine the feasibility of the item in question. The analysis by comparing the value of corrected item-total correlation with the value of $r$ table, using $\alpha$ level of 0.05 , shows that the value of each indicator is above the value of $r$ tables of 0.176. Thus, it can be stated that the overall indicator is valid (Ghozali, 2001). Reliability test by comparing the value of the coefficient alpha with the criteria of a minimum value of 0.6 , resulting in the value of the construct of psychological contract, organisational support, organisational commitment and OCB is above 0.6. Thus, it can be concluded that the whole construct used in the study is reliable (Table 1).

\section{Goodness of fit testing}

The testing results show that the value of chi-square (109.483) is smaller than the value of $r$ table (133.476) with a significant degree of $5 \%$, the probability value (0.198) above the 0.05 criterion; the value of GFI (0.921), is greater than cut-off value (0.90); TLI value (0.947), is greater than cut-off value (0.90); the value of CMIN/DF (1.138) and RMSEA value $(0.024)$ is below the cut-off value $(2.00$ and 0.08 , respectively). Based on these results, the model can be categorised as fit (Table 2).

TABLE 1: Validity and reliability testing results.

\begin{tabular}{lccc}
\hline Constructs & Alpha coefficients & Indicator & $\begin{array}{c}\text { Corrected item-total } \\
\text { correlation }\end{array}$ \\
\hline Psychological contract & 0.702 & PC 1 & 0.604 \\
& & PC 2 & 0.517 \\
& & PC 3 & 0.582 \\
Organisational support & 0.784 & PC 4 & 0.316 \\
& & OS 1 & 0.460 \\
& & OS 2 & 0.601 \\
Organisational commitment & 0.819 & OS 3 & 0.669 \\
& & OS 4 & 0.637 \\
& & OC 1 & 0.598 \\
Organisational citizenship & 0.756 & OC 2 & 0.662 \\
behaviour & & OC 3 & 0.626 \\
& OC 4 & 0.691 \\
& & OCB 1 & 0.376 \\
& & OCB 2 & 0.651 \\
\hline
\end{tabular}

PC, psychological contract; OS, organisational support; OC, organisational commitment; OCB, organisational citizenship behaviour.

TABLE 2: Results of feasibility model.

\begin{tabular}{lccc}
\hline Goodness of fit index & Cut of value & Results analysis & Evaluation model \\
\hline Chi-square & 133476 & 109483 & Good \\
Probability & $\geq 0.05$ & 0198 & Good \\
GFI & $\geq 0.90$ & 0921 & Good \\
TLI & $\geq 0.90$ & 0947 & Good \\
CFI & $\geq 0.90$ & 0975 & Good \\
CMIN/DF & $\leq 2.00$ & 1138 & Good \\
RMSEA & $\leq 0.08$ & 0024 & Good
\end{tabular}

GFI, goodness of fit index; TLI, Tucker-Lewis index; CFI; comparative fit index CMIN/DF, comparative fit index/degrees of freedom (the minimum discrepancy); RMSEA, root mean square error of approximation.

\section{Hypotheses testing \\ The influence of the psychological contract on the organisational commitment}

The testing result of the relationship between the psychological contract and the organisational commitment shows the value of CR is 2.385 with the probability of 0.000 (see Table 3). Thus, the first hypothesis is accepted. This result reveals that the better the psychological contract dealt between the employees and the company is, the bigger the employee organisational commitment is.

\section{The influence of the psychological contract to organisational citizenship behaviour}

The testing result of the relationship between the psychological contract and OCB shows that the value of CR was 2.785 with the probability of 0.000 . This result shows that the better the employees' perception to the psychological contract created by business owners, the bigger the employees OCB. Thus, the second hypothesis is accepted.

\section{The influence of the organisational support on the organisational commitment}

The testing result of the relationship between the psychological contract and OCB shows the value of $C R$ at 2.388 with the probability of 0.000 . This result tells that the bigger the organisational support assumed by the employees, the bigger their commitment. Thus, the third hypothesis is accepted.

\section{The influence of the organisational support on the organisational citizenship behaviour}

The testing result of the relationship between the psychological contract and OCB shows the value of CR was 2.063 with the probability of 0.000 . This result explains that the higher the level of support given by the organisation, the better the employees' OCB. Thus, the hypothesis is accepted.

\section{The influence of organisational commitment on organisational citizenship behaviour}

The testing result of the relationship between the psychological contract and OCB shows the value of $C R$ at 2.723 with the probability of 0.000 . Thus, the hypothesis is accepted.

TABLE 3: Hypotheses testing.

\begin{tabular}{lcc}
\hline Hypothesis & CR-value & $p$-value \\
\hline $\begin{array}{l}\text { H1: The influence of the psychological contract on the } \\
\text { organisational commitment }\end{array}$ & 2.385 & 0.000 \\
$\begin{array}{l}\text { H2: The influence of the psychological contract on the } \\
\text { organisational commitment organisational citizenship behaviour }\end{array}$ & 2.785 & 0.000 \\
$\begin{array}{l}\text { H3: The influence of the organisational support on the } \\
\text { organisational commitment }\end{array}$ & 2.388 & 0.000 \\
$\begin{array}{l}\text { H4: The influence of the organisational support on the } \\
\text { organisational citizenship behaviour }\end{array}$ & 2.063 & 0.000 \\
$\begin{array}{l}\text { H5: The influence of the organisational commitment on the } \\
\text { organisational citizenship behaviour }\end{array}$ & 2.723 & 0.000 \\
\hline
\end{tabular}

$\mathrm{CR}$, critical ratio. 


\section{Discussion}

This study empirically examines the effect of psychological contract particularly on the aspects of relational and organisational support to the organisational commitment and OCB in small-scale businesses owned by the millennial entrepreneurs. The results show a positive influence of the psychological contract on the organisational commitment (see Figure 1). This result confirms the previous findings by Flood et al. (2001), Coyle-Shapiro and Kessler (2000), Aubé, Rousseau and Morin (2007), revealing that the psychological contract affects employee commitment.

This result reveals that psychological contract perceived by employees about the implicit agreement between the business owner and employees consisting of the expectations and needs of employees determines the formation of employees' commitment. Emotionally, employees' attachment to the workplace and the feeling of belonging is formed by the employees' perception to the business owners in providing opportunities for employees' career development and self-actualisation through various training programs aimed at improving the skills of employees.
The fulfilment of the needs of employees can be implemented by creating a pleasant working environment and by establishing great togetherness and effective communication.

The psychological contract is based on the perception of each responsibility, and reciprocal provisions, of both parties (McShane \& Von Gilnow, 2003). Though the contract is not written, yet it is actually very constructive for both sides. Business owners provide access to compensation, competitive rewards and according to their employees a large number of opportunities to excel in their professionalism. On the contrary, employees dedicate their capabilities on an ongoing basis in the form of increased productivity and extra effort for the advancement of business (Mathis \& Jackson, 2007). Chen and Kao (2012), Hu et al. (2014) stated that, psychological contract effects on the citizenship behaviour of employees. Organisation's efforts to meet the needs of employees can encourage the level of active contribution employees can make to achieve the success of the business. Employees' active-participation in giving suggestions for innovative ideas and in working together tends to improve their level of participation in maintaining the positive image of the business where they work.

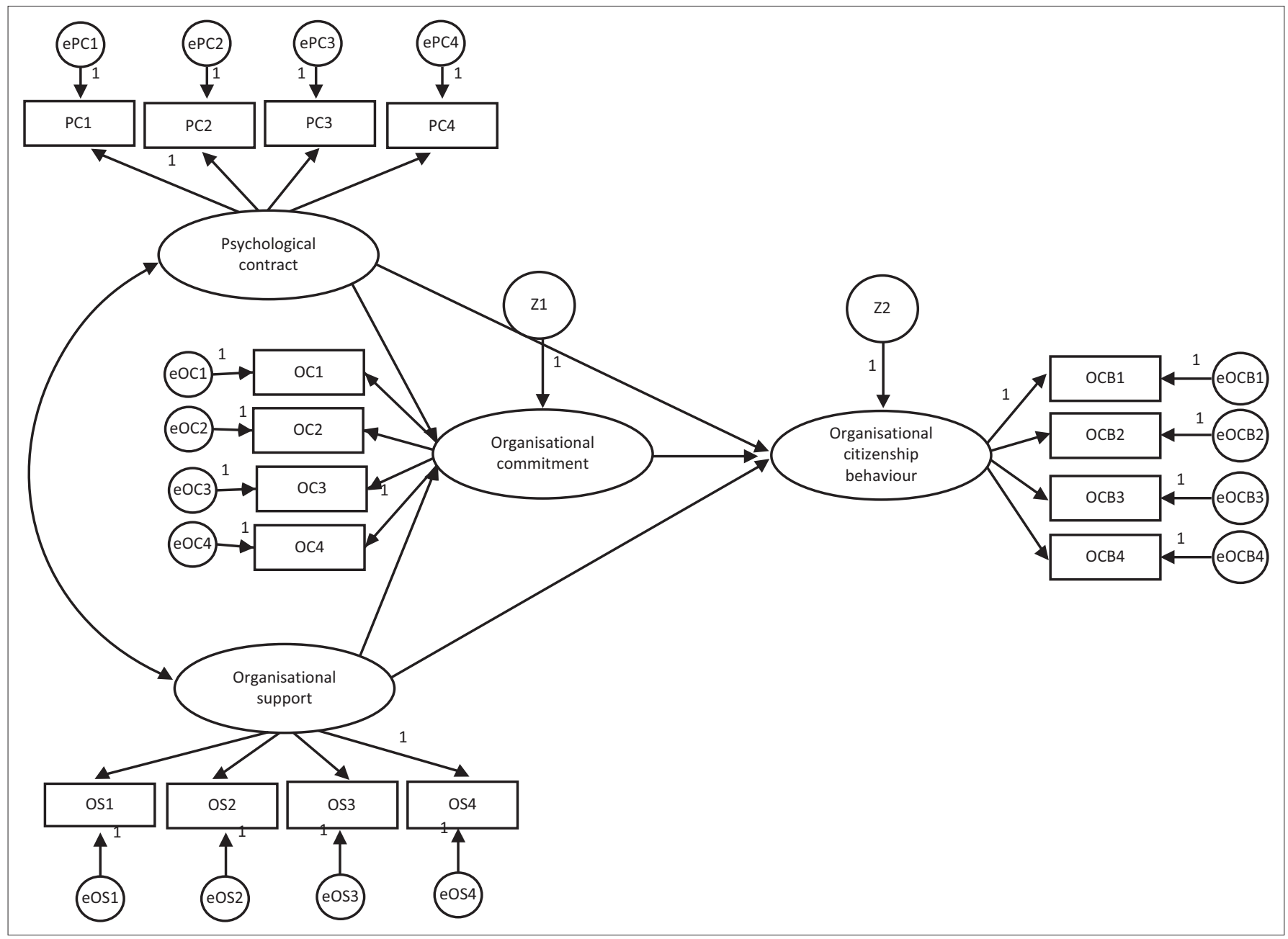

ePC, residual value of psychological contract indicators; PC, psychological contract; eOS, residual value of organisational support indicators; OS, organisational support; eOC, residual value of organisational commitment indicators; OC, organisational commitment; eOCB, residual value of organisational citizenship behaviour indicators; OCB, organisational citizenship behaviour; Z, residual value of regression

FIGURE 1: Research model. 
The results also show the significant influence of the organisational support on the organisational commitment. This result confirms the previous empirical findings by Flood et al. (2001), Coyle-Shapiro and Kessler (2000), Aubé, Rousseau and Morin (2007), revealing that the organisational support influences employee commitment.

The psychological contract as indicated by the fulfilment of the employees' need and the establishing harmonious social relations is the impetus for the emotional attachment of employees with the organisation. The challenging work is more likely to give attachment of employees with the values and goals of the organisation, and the inspiration for achieving the organisational goals. This result shows that the organisational support from business owners significantly encourages the employees' positive commitment. This has the implication to organisational support to the impetus for the initiative, the participation of employees in the decision making, and the internalisation of the values embraced by the business owners.

The organisational support is believed to have a positive effect on the OCB. This result confirms the studies conducted by Chen and Kao (2012), Hu et al. (2014), which stated that organisational support to the employees' citizenship behaviour. Organisational commitment is indicated by the level of employees' internalisation of the values of the organisation and engagement in achieving the goals. The organisational support through the cooperation with its employees to encourage their job initiatives can help them to provide constructive ideas for business development. The organisational consideration in treating employees as a job partner can improve the level of emotional attachment, and eventually, they are willing to contribute to the progress of the business. Organisational support is more likely to encourage employees to work according to their ability and contribute ideas and the voluntary citizenship work for the organisation.

Finally, there are positive influences of organisational commitment on OCB. This result confirms the findings of Davoudi (2012), Gautam et al. (2005), revealing that the organisational commitment influences OCB.

Hence, emotional attachment as a form of the employees' commitment is more likely to influence the citizenship behaviour. This bond tends to encourage the level of employees' participation to think effectively in developing and achieving the organisational goals. Employees' attachment to the work place and colleagues also encourages them to get involved in working together in a harmonious environment and to build the positive image of the organisation.

\section{Limitations and recommendations}

This study used transactional and relational dimensions in psychological contract measurement. However, literature categorised psychological contract into three dimensions including transactional, relational and balanced contract (for instance, Hui et al., 2004). Future studies should consider involving balanced dimension in the measurement. This study analysed the influence of psychological contract on OCB. By considering the business managed by the millennial generation orienting in innovation, future studies should explore the influence of psychological contract on innovative behaviour of employees.

\section{Practical implications}

Primarily, this study provides insightful analysis of organisational psychology regarding the success of employee management relationship of SMEs run by the millennial generation. It is worth mentioning that the characteristics of the millennial generation in building the social relationship with employees allow the process of identifying the needs of employees. Business enterprises managed by the millennial can encourage the employees' contribution to the company. Employees who are able to perform beyond the job description have a strong commitment and are able to balance their personal principles and the morality held by the organisation where they work (Luthans, Norman \& Hughes, 2006). The support given by the owners to the employees indicates that the company cares about the contributions of the employees and the welfare of them (Rhoades et al., 2001). Rhoades and Eisenberger (2002) pointed out that the employees receiving more company support will dedicate their extra-role performances like being more responsible for their work, aiding their work partners and giving their inventive ideas. Similarly, Duffy and Lily (2013) stated that the company support affects the OCB of the employees to work beyond the minimal requirements of the job and provides a positive impact on the achievement of corporate goals.

On the contrary, this provides an opportunity for business owners to share their work values and goals to be achieved by the employees. This value is reflected on the level of employees 'perception related to the relational agreement with business owners in the form of positive psychological contract that can be implemented through the employees' training and gathering for the fulfilment of employees' needs, personal development and creating a pleasant atmosphere in the workplace.

This generation seems to work with strict targets, which can be interpreted as a challenge for employees. However, their flexible working relationship also allows more space for employees to be involved in the decision making process. This is reflected in some organisational supports perceived by employees in providing appreciation and reward to their job, and facilitating their opinions as one of business solutions. Generation $\mathrm{Y}$ is likely to consider the employees as working partners, and give more space to employees to show their initiatives, innovation and constructive ideas for business development. These factors lead to employees' emotional attachment to the work place and their willingness to actively contribute to the progress of the business. 
This study implies the need for academic institutions and policy makers to get involved in addressing the rising phenomenon of entrepreneurship among the young generation, especially the millennial generation. They need to design the innovative and applicable training for young entrepreneurs in order to facilitate them in searching for business opportunities and orientation.

\section{Acknowledgements}

The authors would like to thank Diponegoro University Semarang for research support, and two anonymous reviewers for their valuable comments.

\section{Competing interests}

The authors declare that they have no financial or personal relationships which may have inappropriately influenced them in writing this article.

\section{Authors' contributions}

A.A. was the main project leader and data collector. C.D. and A.Y. were the supervisors of the project.

\section{References}

Allen, D.G., \& Shanock, L.R. (2013). Perceived organizational support and embeddedness as key mechanisms connecting socialization tactics to commitment and turnover among new employees. Journal of Organizational Behavior, 34(3) 350-369. https://doi.org/10.1002/job.1805

Allen, N.J., \& Meyer, J.P. (1990). Organizational socialization tactics: A longitudinal analysis of links to newcomers' commitment and role orientation. Academy of Management Journal, 33(4), 847-858. https://doi.org/10.2307/256294

Argyris, C. (1960). Understanding organizational behaviour. London: Tavistock Publications.

Aubé, C., Rousseau, V., \& Morin, E.M. (2007). Perceived organizational support and organizational commitment: The moderating effect of locus of control and work autonomy. Journal of Managerial Psychology, 22(5), 479-495. https://doi. org/10.1108/02683940710757209

Beardwell, I., Holden, L., \& Claydon, T. (2004). Human resource management, a contemporary approach. (4th edn.). Harlow: Financial Times Prentice Hall.

Bentley, T.A., Teo, S.T.T., McLeod, L., Tan, F., Bosua, R., \& Gloet, M. (2016). The role of organisational support in teleworker wellbeing: A socio-technical systems approach. Applied Ergonomics, 52, 207-215. https://doi.org/10.1016/j.apergo. 2015.07.019

Borman, W.C., \& Motowidlo, S.J. (1997). Task performance and contextual performance: The meaning for personnel selection research. Human Performance, 10(2), 99-109. https://doi.org/10.1207/s15327043hup1002_3

Burstein, D.D. (2013). Fast future: How the millennial generation is shaping our world. Boston, MA: Beacon Press.

Byrne, Z.S., \& Hochwarter, W.A. (2008). Perceived organizational support and performance: Relationships across levels of organizational cynicism. Journal of ManagerialPsychology, 23(1), 54-72.https://doi.org/10.1108/02683940810849666

Chen, C.H.V., \& Kao, R.H. (2012). Work values and service-oriented organizational citizenship behaviors: The mediation of psychological contract and professional commitment: A case of students in Taiwan Police College. Social Indicators Research, 107(1), 149-169. https://doi.org/10.1007/s11205-011-9832-7

Choi, N., \& Majumdar, S. (2014). Social entrepreneurship as an essentially contested concept: Opening a new avenue for systematic future research. Journal of Business Venturing, 29(3), 363-376. https://doi.org/10.1016/j.jbusvent.2013. 05.001

Chun, J.S., Shin, Y., Choi, J.N., \& Kim, M.S. (2013). How does corporate s contribute to firm financial performance? The mediating role of collective organizational commitment and organizational citizenship behavior. Journal of Management 39(4), 853-877. https://doi.org/10.1177/0149206311419662

Coyle-Shapiro, J., \& Kessler, I. (2000). Consequences of the psychological contract for the employment relationship: A large scale survey. Journal of Management Studies, 37(7), 903-930. https://doi.org/10.1111/1467-6486.00210

Davoudi, S.M. (2012). Organizational commitment and extra-role behaviour: A survey in Iran's insurance industry. Journal of Business Systems, Governance \& Ethics, $7(1), 66-75$

Duffy, J.A., \& Lilly, J. (2013). Do individual needs moderate the relationships between organizational citizenship behavior, organizational trust and perceived organizational support? Journal of Behavioral and Applied Management, 14(3), 185.
Eisenberger, R., Huntington, R., Hutchison, S., \& Sowa, D. (1986). Perceived organizational support. Journal of Applied Psychology, 71, 500-507. https://doi. org/10.1037/0021-9010.71.3.500

Eisenberger, R., Malone, G.P., \& Presson, W.D. (2016). Optimizing perceived organizational support to enhance employee engagement. Bowling Green, Ohio USA: Society for Human Resource Management and Society for Industrial and Organizational Psychology.

Ferri-Reed, J. (2015). 'Millennializing' the work environment. The Journal for Quality and Participation, 37(4), 17.

Festing, M., \& Schäfer, L. (2014). Generational challenges to talent management: A framework for talent retention based on the psychological-contract perspective. Journal of World Business, 49(2), 262-271. https://doi.org/10.1016/j. jwb.2013.11.010

Flood, P.C., Turner, T., Ramamoorthy, N., \& Pearson, J. (2001). Causes and consequences of psychological contracts among knowledge workers in the high technology and financial services industries. International Journal of Human Resource Management, 12(7), 1152-1165. https://doi.org/10.1080/09585190110068368

Gautam, T., Van Dick, R., Wagner, U., Upadhyay, N., \& Davis, A.J. (2005) Organizational citizenship behavior and organizational commitment in Nepal. Asian Journal of Social Psychology, 8(3), 305-314. https://doi.org/10.1111/ j.1467-839X.2005.00172.x

George, J.M., \& Jones, G.R. (1997). Organizational spontaneity in context. Human Performance, 10(2), 153-170. https://doi.org/10.1207/s15327043hup1002_6

Ghozali, I. (2001). Multivariate dengan program SPSS. Semarang: Badan Penerbit Universitas Diponegoro.

Given, L.M. (2008). The Sage encyclopedia of qualitative research methods. Los Angeles, CA: Sage.

Guchait, P., Cho, S., \& Meurs, J.A. (2015). Psychological contracts, perceived organizational and supervisor support: Investigating the impact on intent to leave among hospitality employees in India. Journal of Human Resources in Hospitality \& Tourism, 14(3), 290-315. https://doi.org/10.1080/15332845.2015.1002070

Guest, D.E. (2016). Trust and the role of the psychological contract in contemporary employment relations. In P. Elgoibar, L. Munduate, \& M. Euwema (Eds). Building trust and constructive conflict management in organizations (pp. 137-149). Switzerland: Springer International Publishing.

Hair, J.F., Anderson, R.E., Tatham, R.L., \& Black, W.C. (1992). Multivariate data analysis. (3rd edn.). New York: Macmillan.

Harney, B., \& Dundon, T. (2006). Capturing complexity: Developing an integrated approach to analysing HRM in SMEs. Human resource Management Journal, 16(1), 48-73. https://doi.org/10.1111/j.1748-8583.2006.00004.x

Herriot, P., \& Pemberton, C. (1997). Facilitating new deals. Human Resource Management Journal, 7(1), 45-56. https://doi.org/10.1111/j.1748-8583.1997. tb00273.x

Hu, C., Wang, S., Yang, C.C., \& Wu, T.Y. (2014). When mentors feel supported Relationships with mentoring functions and protégés' perceived organizational support. Journal of Organizational Behavior, 35(1), 22-37. https://doi. org/10.1002/job.1851

Hu, L., \& Bentler, P.M. (1999). Cutoff criteria for fit indexes in covariance structure analysis: Conventional criteria versus new alternatives. Structural Equation Modeling, 6(1), 1-55. https://doi.org/10.1080/10705519909540118

Hui, C., Lee, C., \& Rousseau, D.M. (2004). Psychological contract and organizational citizenship behavior in China: Investigating generalizability and instrumentality. Journal of Applied Psychology, 89(2), 311. https://doi.org/10.1037/0021 9010.89.2.311

Jain, A.K., Giga, S.I., \& Cooper, C.L. (2013). Perceived organizational support as a moderator in the relationship between organisational stressors and organizational citizenship behaviors. International Journal of Organizational Analysis, 21(3), 313-334. https://doi.org/10.1108/IJOA-Mar-2012-0574

Karagonlar, G., Eisenberger, R., \& Aselage, J. (2016). Reciprocation wary employees discount psychological contract fulfillment. Journal of Organizational Behavior, discount psychological contract fulfillment. Jou
37(1), 23-40. https://doi.org/10.1002/job.2016

Katz, D. (1964). The motivational basis of organizational behavior. Behavioral Science, 9(2), 131-146. https://doi.org/10.1002/bs.3830090206

Kiazad, K., Kraimer, M., \& Seibert, S. (2014a). A job embeddedness perspective on responses to psychological contract fulfillment. In Academy of management proceedings (Vol. I, p. 12362). Briarcliff Manor, NY: Academy of Management.

Kiazad, K., Seibert, S.E., \& Kraimer, M.L. (2014b). Psychological contract breach and employee innovation: A conservation of resources perspective. Journal of Occupational and Organizational Psychology, 87(3), 535-556. https://doi. org/10.1111/joop.12062

Kilian, T., Hennigs, N., \& Langner, S. (2012). Do Millennials read books or blogs? Introducing a media usage typology of the internet generation. Journa of Consumer Marketing, 29(2), 114-124. https://doi.org/10.1108/073637612 11206366

Kim, K.Y., Eisenberger, R., \& Baik, K. (2016). Perceived organizational support and affective organizational commitment: Moderating influence of perceived organizational competence. Journal of Organizational Behavior, 37(4), 558-583. https://doi.org/10.1002/job.2081

Koe, W.L., Sa'ari, J.R., Majid, I.A., \& Ismail, K. (2012). Determinants of entrepreneurial intention among millennial generation. Procedia-Social and Behavioral Sciences, 40, 197-208. https://doi.org/10.1016/j.sbspro.2012.03.181

Kraft, E., \& Wang, J. (2010). An exploratory study of the cyberbullying and cyberstalking experiences and factors related to victimization of students at a public liberal arts college. International Journal of Technoethics (IJT), 1(4), 74-91. https://doi. org/10.4018/jte.2010100106 
Lee, H.W., \& Lin, M.C. (2014). A study of salary satisfaction and job enthusiasm Mediating effects of psychological contract. Applied Financial Economics, 24(24), 1577-1583. https://doi.org/10.1080/09603107.2013.829197

Low, C.H., Bordia, P., \& Bordia, S. (2016). What do employees want and why? An exploration of employees' preferred psychological contract elements across career stages. Human Relations, 69(7), 1457-1481. https://doi.org/10.1177/ 0018726715616468

Luthans, F., Norman, S., \& Hughes, L. (2006). Authentic leadership. In J. Zenger, J. Folkman, \& S. Edinger (Eds.), The inspiring leader: Unlocking the secrets of how extraordinary leaders motivate (pp. 84-104). New York: McGraw Hill Professional.

Mathis, R.L., \& Jackson, J.H. (2007). Human resource management: Essential perspectives. (4th edn.). Mason, $\mathrm{OH}$ : Thomson South-Western.

McInnis, K.J., Meyer, J.P., \& Feldman, S. (2009). Psychological contracts and their implications for commitment: A feature-based approach. Journal of Vocationa Behavior, 74(2), 165-180. https://doi.org/10.1016/j.jvb.2008.12.007

McShane, S.L., \& Von Gilnow, M.A. (2003). Organizational behavior: Emerging realities for the workplace revolution. (2nd edn.). New York: McGraw-Hill.

Meyer, J.P., \& Allen, N.J. (1997). Commitment in the work place. Thousand Oak, CA: Sage.

Meyer, J.P., \& Herscovitch, L. (2001). Commitment in the workplace: Toward a general model. Human Resource Management Review, 11(3), 299-326. https://doi. model. Human Resource Manageme
org/10.1016/S1053-4822(00)00053-X

Miao, R.T. (2011). Perceived organizational support, job satisfaction, task performance and organizational citizenship behavior in China. Journal of Behavioral and Applied Management, 12(2), 105.

Moorman, R.H. (1991). Relationship between organizational justice and organizational citizenship behaviors: Do fairness perceptions influence employee citizenship? Journal of Applied Psychology, 76(6), 845. https://doi.org/10.1037/00219010.76.6.845

Morrison, E.W., \& Robinson, S.L. (1997). When employees feel betrayed: A model of how psychological contract violation develops. Academy of Management Review, 22(1), 226-256.

Moscardo, G., \& Benckendorff, P. (2010). Mythbusting: Generation Y and travel. In P. Benckendorff, G. Moscardo, \& D. Pendergast (Eds.), Tourism and generation (pp. 16-26). Oxfordshire: Cabi.

Mowday, R.T., Porter, L.W., \& Steers, R.M. (1982). Employee - Organization linkages: The psychology of commitment, absenteeism, and turnover. New York: Academic Press.

Nelson, D.W. (2015). Millennial social networking behavior from a uses and gratifications perspective. Raleigh, NC: North Carolina State University.

Ng, T.W., Feldman, D.C., \& Butts, M.M. (2014). Psychological contract breaches and employee voice behaviour: The moderating effects of changes in social relationships. European Journal of Work and Organizational Psychology, 23(4), 537-553. https://doi.org/10.1080/1359432X.2013.766394

O'Reilly, C.A., \& Chatman, J. (1986). Organizational commitment and psychological attachment: The effects of compliance, identification, and internalization on prosocial behavior. Journal of Applied Psychology, 71(3), 492. https://doi. org/10.1037/0021-9010.71.3.492

Organ, D.W. (1997). Organizational citizenship behavior: It's construct clean-up time. Human Performance, 10(2), 85-97. https://doi.org/10.1207/ s15327043hup1002_2

Panaccio, A., Henderson, D.J., Liden, R.C., Wayne, S.J., \& Cao, X. (2015). Toward an understanding of when and why servant leadership accounts for employee extrarole behaviors. Journal of Business and Psychology, 30(4), 657-675. https://doi. org/10.1007/s10869-014-9388-z

Panaccio, A., \& Vandenberghe, C. (2009). Perceived organizational support, organizational commitment and psychological well-being: A longitudinal study. Journal of Vocational Behavior, 75(2), 224-236. https://doi.org/10.1016/j. Journal of Vocatic

Pendergast, D. (2010). Getting to know the Y generation. In P. Benckendorff, G. Moscardo, \& D. Pendergast (Eds.), Tourism and generation (pp. 1-15). Oxfordshire: Cabi.

Podsakoff, P.M., Mackenzie, S.B., Paine, J.B., \& Bachrach, D.G. (2000). Organizational citizenship behaviors: A critical review of the theoretical and empirical literature and suggestions for future research. Journal of Management, 26(3), 513-563. https://doi.org/10.1177/014920630002600307

Priesemuth, M., \& Taylor, R.M. (2016). The more I want, the less I have left to give: The moderating role of psychological entitlement on the relationship between psychological contract violation, depressive mood states, and citizenship behavior. Journal of Organizational Behavior, 37(7), 967-982. https://doi.org/10.1002/ job.2080

Rahman, A., Hayati, N., Sahiq, M., Nadiah, A., Ismail, S., Bakri, M.H., et al. (2016). Antecedents of a successful business venture for young entrepreneurs. Advanced Science Letters, 22(12), 4485-4488.
Rayton, B.A., \& Yalabik, Z.Y. (2014). Work engagement, psychological contract breach and job satisfaction. The International Journal of Human Resource Management, 25(17), 2382-2400. https://doi.org/10.1080/09585192.2013.876440

Rhoades, L., \& Eisenberger, R. (2002). Perceived organizational support: A review of the literature. Journal of Applied Psychology, 87(4), 698. https://doi. org/10.1037/0021-9010.87.4.698

Rhoades, L., Eisenberger, R., \& Armeli, S. (2001). Affective commitment to the organization: The contribution of perceived organizational support. Journal of Applied Psychology, 86(5), 825. https://doi.org/10.1037/0021-9010.86.5.825

Richardson, S. (2010). 12 understanding generation Y's attitudes towards the industry. In P. Benckendorff, G. Moscardo, \& D. Pendergast (Eds.), Tourism and generation (pp. 131-142). Oxfordshire: Cabi.

Ridley-Duff, R., \& Bull, M. (2015). Understanding social enterprise: Theory and practice. London: Sage.

Ristig, K. (2009). The impact of perceived organizational support and trustworthiness on trust. Management Research News, 32(7), 659-669. https://doi. org/10.1108/01409170910965251

Rousseau, D. (1995). Psychological contracts in organizations: Understanding written and unwritten agreements. Thousand Oaks, CA: Sage.

Rousseau, D.M. (1989). Psychological and implied contracts in organizations. Employee Responsibilities and Rights Journal, 2(2), 121-139. https://doi.org/10.1007/ BF01384942

Sago, B. (2010). The influence of social media message sources on millennial generation consumers. International Journal of Integrated Marketing Communications, 2(2), 7-18.

Saks, A.M. (2006). Antecedents and consequences of employee engagement. Journal of Managerial Psychology, 21(7), 600-619. https://doi.org/10.1108/ 02683940610690169

Shahin, A., Shabani Naftchali, J., \& Khazaei Pool, J. (2014). Developing a model for the influence of perceived organizational climate on organizational citizenship behaviour and organizational performance based on balanced score card. International Journal of Productivity and Performance Management, 63(3), 290307. https://doi.org/10.1108/IJPPM-03-2013-0044

Shen, Y., Jackson, T., Ding, C., Yuan, D., Zhao, L., Dou, Y., et al. (2014). Linking perceived organizational support with employee work outcomes in a Chinese context: Organizational identification as a mediator. European Management Journal, 32(3), 406-412. https://doi.org/10.1016/j.emj.2013.08.004

Smith, C.A., Organ, D.W., \& Near, J.P. (1983). Organizational citizenship behavior: Its nature and antecedents. Journal of Applied Psychology, 68(4), 653. https://doi. org/10.1037/0021-9010.68.4.653

Sparrow, P., \& Cooper, C.L. (1998). New organizational forms: The strategic relevance of future psychological contract scenarios. Canadian Journal of Administrative Sciences, 15(4), 356-371. https://doi.org/10.1111/j.1936-4490.1998.tb00177.x

Steers, R.M. (1977). Antecedents and outcomes of organizational commitment. Administrative Science Quarterly, 22, 46-56. https://doi.org/10.2307/2391745

Sturges, J., Conway, N., Guest, D., \& Liefooghe, A. (2005). Managing the career deal: The psychological contract as a framework for understanding career management, organizational commitment and work behavior. Journal of Organizational Behavior, 26(7), 821-838. https://doi.org/10.1002/job.341

Taylor, A. (2012). A study of the information search behaviour of the millennial generation. Information Research: An International Electronic Journal, 17(1), 20.

Thomas, D.C., Ravlin, E.C., Liao, Y., Morrell, D.L., \& Au, K. (2016). Collectivist values, exchange ideology and psychological contract preference. Management International Review, 56(2), 255-281. https://doi.org/10.1007/ s11575-015-0275-2

Van den Heuvel, S., Schalk, R., \& Van Assen, M.A. (2015). Does a well-informed employee have a more positive attitude toward change? The mediating role of psychological contract fulfillment, trust, and perceived need for change. The Journal of Applied Behavioral Science, 51(3), 401-422. https://doi. org/10.1177/0021886315569507

Van Dyne, L., Graham, J.W., \& Dienesch, R.M. (1994). Organizational citizenship behavior: Construct redefinition, measurement, and validation. Academy of Management Journal, 37(4), 765-802. https://doi.org/10.2307/256600

Van Praag, C.M. (2003). Business survival and success of young small business owners. Small Business Economics, 21(1), 1-17. https://doi.org/10.1023/A:1024453200297

Williams, L.J., \& Anderson, S.E. (1991). Job satisfaction and organizational commitment as predictors of organizational citizenship and in-role behaviors. Journal of
Management, 17(3), 601-617. https://doi.org/10.1177/014920639101700305

Xerri, M.J., \& Brunetto, Y. (2013). Fostering innovative behaviour: The importance of employee commitment and organisational citizenship behaviour. The International Journal of Human Resource Management, 24(16), 3163-3177. https://doi.org/10. Journal of Human Resource Mand
108585192.2013.775033

Yadin, A. (2012). Millennials and privacy in the information age: Can they coexist? IEEE Technology and Society Magazine, 31(4), 32-38. https://doi.org/10.1109/ MTS.2012.2225461 